\title{
Study on the Teaching Strategies for Undergraduates of English Majors Based on Learning Style
}

\author{
Juju Wang \\ School of Foreign Languages \\ Qilu Normal University \\ Jinan, China 250013
}

\begin{abstract}
The minds and physiology of college students has been mature and they have possessed stronger independence and have basically formed their stable and effective learning skills and possessed the suitable learning strategies to acquire what teachers have taught. It is shown in the research that the teaching strategies aiming at the styles of students are very important. When the learning strategies of students can conform to their learning styles, their motivation will be greatly increased and they will possess greater responsibilities in learning and will achieve better results. The satisfaction, anxiety and emotion of students have lots to do with the teaching methods of teachers. in the past, there are many researches conducting the investigations in the term of questionnaires to the learning styles of college students in different majors and different regions. It is found that there are much difference among the learning styles and habits of students in different majors. However, it has not been investigated on how much different in the learning styles of English-majored normal students in their junior and senior periods which is very meaningful for what kinds of teaching strategies should teachers adopt.
\end{abstract}

Keywords-PEPS questionnaire; English-majored normal students; learning styles

\section{INTRODUCTION}

It is considered in the learning style theory that there are different measures for learning in different phases. This theory pays special attention on the study on intelligence quotient, sensory methods, cognition and learning process of students (Evans, Waring, 2012). The learning style model of Kolb pays special attention on how the students process the information. While the model of Dunn focuses on how the student obtain information. The construction foundation of this model is very diversified which have actual support on the learning and teaching methods. He has conducted large number of worldwide researches on children, teenagers and adult students which lasted for five year and those researches are applied in education and medical industries (Dunn, Griggs, 1998). Therefore, the model of Dunn is adopted in this thesis.

The questionnaire in this model is PEPS (Effective Environment Scale). The learning style thereinto refers to the abilities and demands of students when learning the new and

Chinese library classification number: H315.9 Document code: A Phased achievements of the "Study on the Teaching Strategies for Undergraduates of English Majors Based on Learning Style" of Shandong social sciences planning study program (16CZWJ55) difficult knowledge. The factors that impact on the learning styles of learners are divided into environmental factor, emotional factor, social factor, mental and sensory factors. Because this scale needs much information, the teachers will provide many specific and detailed teaching schemes. At the same time, the students can operate by themselves as the reference of independent learning in their lives.

There are over 400 pieces of doctoral thesis and over 500 pieces of research thesis adopting the scale of Dunn. However, there are few of them studying on the English-majored normal students. The personalities of college students are various. Using the PEPS questionnaire to study the learning styles of English-majored normal students is very meaningful. The objectives investigated in this thesis are the English-majored normal undergraduates in the school of foreign languages of Qilu Normal University, because they has adapted to the college life and has possessed certain experience on formulating their own learning plans aiming at the teaching of teachers according to their learning objectives.

\section{STUDY METHODS AND OBJECTIVES}

This thesis conducts the comparative study on the learning styles of Grade 2013 normal undergraduates in the school of foreign languages of Qilu Normal University in the three terms from March 2015 to July 2016 with the objectives of finding the difference in learning styles of students with different personalities.

The simple sample investigation is conducted to total 263 students (209 female students and 54 male students). The respondents learn the same courses during the investigation period and all participate in the final at the end of a term. During this period, the teachers adopt different teaching methods such as lecturing, individual coaching, multimedia teaching, individual and group activities and practice, etc but centering on the classroom teaching.

Two kinds of questionnaires are adopted in this investigation. Adopt the adult PEPS to determine the learning style (Dunn et al., 2000) while adopt another questionnaire to determine the personality characteristics of learners. There are total 100 questions related to 20 learning styles in PEPS and each question is divided into five scales from 1 to 5 of the Likert scale, 1 standing for "never" and 5 standing for "often". 
We can understand the learning styles on different aspects through those teachers and students:

Environmental style: sound, light, temperature and furniture layout.

Emotional style: motivation, responsibility, adaptability, persistence and externally imposed demands or opportunities for independent working.

Social style: participation of authorities, changes, independent learning, two-person or group learning.

Sensory style: preference on the auditory sense, visual sense, tactile sense and kinesthesis sense, vigor levels at different time of a day and mobility.
Students preferring auditory sense will prefer the verbal explanation of teacher and listening exercises while students preferring visual sense will prefer reading and writing, observation and watching videos, etc. Students preferring tactile sense will prefer operation and taking notes for things they are interested in while students preferring kinesthesis sense will prefer learning in dynamic state and learning new knowledge in practice and imitation (Beischel, 2011; Hedin, 2006).

The questionnaire selected for this study is PEPS which possesses good reliability and validity (Griggs et al., 1994). The reliability factor of each factor can be corrected to 75 to 88 (Dunn et al., 1995)."Table I"

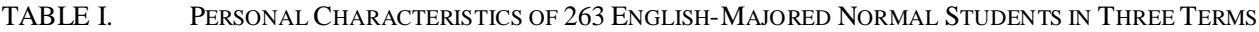

\begin{tabular}{|c|c|c|c|c|c|c|c|c|c|}
\hline \multirow[t]{3}{*}{$\begin{array}{c}\text { Variabl } \\
\text { e }\end{array}$} & & Class & & $\begin{array}{c}\text { Term } \\
\text { (including } \\
\text { six courses) }\end{array}$ & & & Total & Comparison & \\
\hline & & Class $A$ & Class B & $\begin{array}{c}\text { First half of } \\
2015\end{array}$ & $\begin{array}{c}\text { Second } \\
\text { half of } \\
2015\end{array}$ & $\begin{array}{c}\text { First half } \\
\text { of } 2016\end{array}$ & $\begin{array}{c}n=263 \\
\%\end{array}$ & $\begin{array}{c}\text { Comparison } \\
\text { between } \\
\text { classes }\end{array}$ & $\begin{array}{c}\text { Comparison among } \\
\text { terms }\end{array}$ \\
\hline & & $\begin{array}{l}\mathrm{n}=125 \\
\%\end{array}$ & $\begin{array}{l}\mathrm{n}=138 \\
\%\end{array}$ & $\mathrm{n}=78 \%$ & $\mathrm{n}=72 \%$ & $\mathrm{n}=113 \%$ & & & \\
\hline \multirow[t]{2}{*}{ Sex } & $\begin{array}{l}\text { Fema } \\
\text { le }\end{array}$ & 74.4 & 84.1 & 78.2 & 84.7 & 77.0 & 79.5 & $X 2(1)=3.75$ & $X 2(2)=1.719$ \\
\hline & Male & 25.6 & 15.9 & 21.8 & 15.3 & 23.0 & 20.5 & $\mathrm{P}=0.053 \mathrm{n} . \mathrm{s}$. & $\mathrm{P}=0.423 \mathrm{n} . \mathrm{s}$. \\
\hline \multirow[t]{3}{*}{ Age } & $17-18$ & 25.6 & 12.3 & 21.8 & 9.7 & 22.1 & 18.6 & $\begin{array}{l}\text { Mann-- } \\
\text { Whitney }\end{array}$ & Kruskal-Wallis test \\
\hline & $19-20$ & 19.2 & 26.8 & 25.6 & 27.8 & 18.6 & 23.2 & U-test 7919.5 & $X 2(2)=1.238$ \\
\hline & $20-21$ & 16.8 & 19.6 & 11.5 & 22.2 & 20.35 & 18.3 & $Z=-1.150$ & $\mathrm{P}=0.538$ n.s. \\
\hline \multirow[t]{2}{*}{ TEM-4 } & Pass & 24.8 & 19.6 & 19.2 & 23.6 & 23.0 & 22.1 & $X 2(1)=1.046$ & $X 2(2)=0.523$ \\
\hline & Fail & 75.2 & 80.4 & 80.8 & 76.4 & 77.0 & 77.9 & $\mathrm{P}=0.307 \mathrm{n} . \mathrm{s}$ & $\mathrm{P}=0.770 \mathrm{n} . \mathrm{s}$ \\
\hline
\end{tabular}

\section{STUDY PROCESS}

All data is given by the students in classes and is collected by teachers in written and oral forms. The students take about 40 minutes to fill out two kinds of questionnaires the data of absent students shall be independently collected later. After completion of information collection, the results through processing will be sent to the e-mail boxes of students. We hope that those data will be helpful for the further learning of students.

\section{A. Data Analysis}

After being processed by the computer, each type of the PEPS data has a score. The questions in the questionnaire all adopt 80 points as standard and three grades are generated by the computer where low score is 20 to 40 points, medium score is 41 to 60 points and the high score is 61 to 80 points. Those scores are used for inferential statistics. The data of descriptive statistics is used to differentiate the learning types of subjects while the data of inferential statistics is used to detect the similarities and differentia among groups. The Pearson Chisquare detection is used to compare the quantitative data while the Mann Whitney U detection is used to compare the data of sequencing, distance and definite proportion.

\section{StUdy REsUlts}

\section{A. Learning Styles of English-Majored Normal Students During Three Terms from 2015 to 2016}

"Table II" is the data distribution of various idiosyncratic states in PEPS of 263 students. We can see in the table that most of the idiosyncratic data is between 41 and 60 and there are no special tendencies. The scores of several students are less than 40 or over 60 which means that they have special tendencies or special avoidance to the special factors in their learning styles. On the environmental factors, more students prefer the quiet and formal layout. Two thirds of students prefer learning with partners and $4 \%$ of students prefer learning by themselves and $40 \%$ of students prefer that teachers or other tutors are around when learning while $1.1 \%$ of students do not prefer this form. Other $31 \%$ of students prefer auditory and tactile learning, $28 \%$ of students prefer motile learning and $8 \%$ of students prefer visual learning. $33 \%$ of students show that they possess patience for learning, $16 \%$ of students prefer learning of dynamical type while $9 \%$ of students prefer responsible learning. There is no obvious data difference in other styles. 


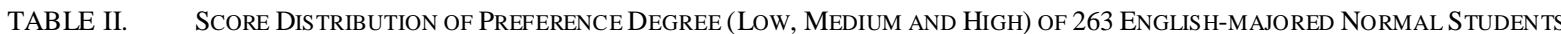

\begin{tabular}{|c|c|c|c|c|c|c|c|c|c|}
\hline \multirow[t]{2}{*}{ Factors $^{1}$} & \multicolumn{3}{|l|}{$\begin{array}{c}\text { Low } \\
\text { Range 20 40 }\end{array}$} & \multicolumn{2}{|c|}{$\begin{array}{c}\text { Medium } \\
\text { Range } \\
41 \sim 60 \\
\end{array}$} & \multicolumn{2}{|l|}{$\begin{array}{c}\text { High } \\
\text { Range } 61 \sim 80\end{array}$} & \multirow[b]{2}{*}{$\%$} & \multirow{2}{*}{$\begin{array}{l}\text { Total value } \\
\mathrm{n}\end{array}$} \\
\hline & & $\mathrm{n}$ & $\%$ & $n$ & $\%$ & & $\mathrm{n}$ & & \\
\hline Noise level & Preferring quietness & 2 & 0.8 & 211 & 80.2 & Preferring noise & 50 & 19.0 & 263 \\
\hline Light & Preferring darkness & 16 & 6.1 & 227 & 86.3 & Preferring lightness & 20 & 7.6 & 263 \\
\hline Indoor temperature & Preferring cool & 29 & 11.0 & 200 & 76.0 & Preferring warmness & 34 & 12.9 & 263 \\
\hline Indoor design & $\begin{array}{l}\text { Preferring informal } \\
\text { design }\end{array}$ & 20 & 7.6 & 192 & 73.0 & $\begin{array}{l}\text { Preferring } \\
\text { design }\end{array}$ & 51 & 19.4 & 263 \\
\hline Learning motivation & Low & 5 & 1.9 & 215 & 81.7 & High & 43 & 16.3 & 263 \\
\hline Learning persistence & Low & 1 & 0.4 & 175 & 66.5 & High & 87 & 33.1 & 263 \\
\hline Responsibility & Low & 29 & 11.0 & 209 & 79.5 & High & 25 & 9.5 & 263 \\
\hline Structure & No preference & 0 & 0.0 & 68 & 25.9 & Preference & 195 & 74.1 & 263 \\
\hline Independence/ partner & $\begin{array}{l}\text { Preferring } \\
\text { independence }\end{array}$ & 11 & 4.2 & 76 & 28.9 & $\begin{array}{l}\text { Preferring accompany } \\
\text { of partner }\end{array}$ & 176 & 66.9 & 263 \\
\hline Authority figure & Absence & 3 & 1.1 & 154 & 58.6 & Presence & 106 & 40.3 & 263 \\
\hline Diversification of measures & No preference & 37 & 14.1 & 216 & 82.1 & $\begin{array}{l}\text { Preferring } \\
\text { diversification }\end{array}$ & 10 & 3.8 & 263 \\
\hline Auditory materials & No preference & 10 & 3.8 & 169 & 64.3 & Preference & 84 & 31.9 & 263 \\
\hline Visual materials & No preference & 42 & 16.0 & 200 & 76.0 & Preference & 21 & 8.0 & 263 \\
\hline Tactile materials & No preference & 12 & 4.6 & 170 & 64.6 & Preference & 81 & 30.8 & 263 \\
\hline Kinesthetic materials & No preference & 2 & 0.8 & 188 & 71.5 & Preference & 73 & 27.7 & 263 \\
\hline Learning inputs & No preference & 23 & 8.7 & 184 & 70.0 & Preference & 56 & 21.3 & 263 \\
\hline Morning & No preference & 41 & 15.6 & 174 & 66.2 & Preference & 48 & 18.2 & 263 \\
\hline Noon & No preference & 48 & 18.2 & 158 & 60.1 & Preference & 57 & 21.7 & 263 \\
\hline Afternoon & No preference & 38 & 14.4 & 149 & 56.7 & Preference & 76 & 28.9 & 263 \\
\hline Student flow & No preference & 6 & 2.3 & 199 & 75.7 & Preference & 58 & 22.0 & 263 \\
\hline
\end{tabular}

The entry adopts Likert scoring method: 1 (never) to 5 (always)

\section{B. Comparison on Learning Styles in Different Classes and} Different Terms

There is no significant difference in the learning styles of different classes. It is only shown in "Table III" that the students in class 2 are more inclined to learning in tactile type $(\mathrm{P}=.004)$. The difference among different terms in "Table IV" is: students are more inclined to auditory learning in first half of academic year of $2015(\mathrm{P}=.028)$ while they are more inclined to visual learning in second half of academic year of 2015 and few students prefer visual learning in first half of academic year of 2016.

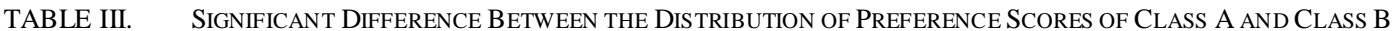

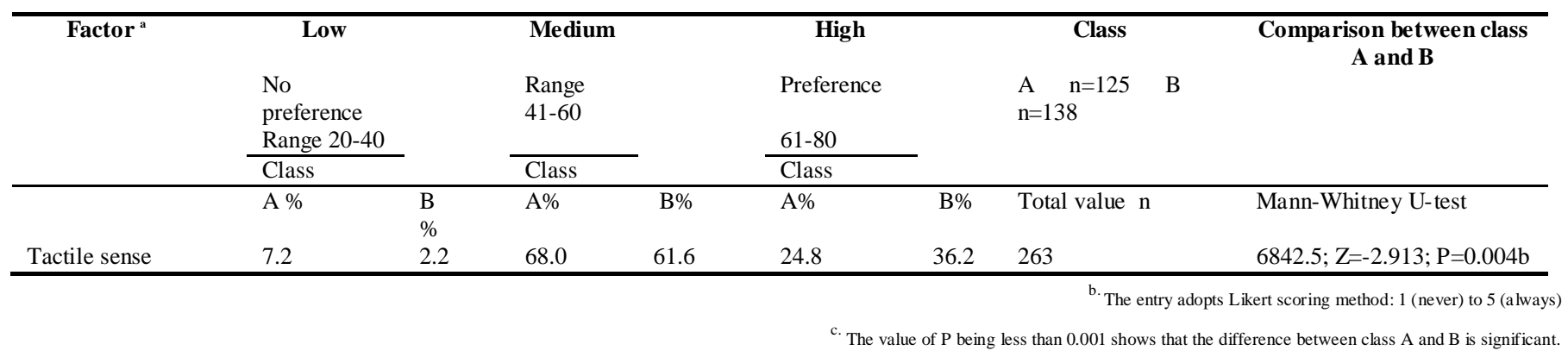


TABLE IV.

SigNIFICANT DifFERENCE OF SCORE Distribution FOR STUDENT PREFERENCE AMONG THREE TERMS

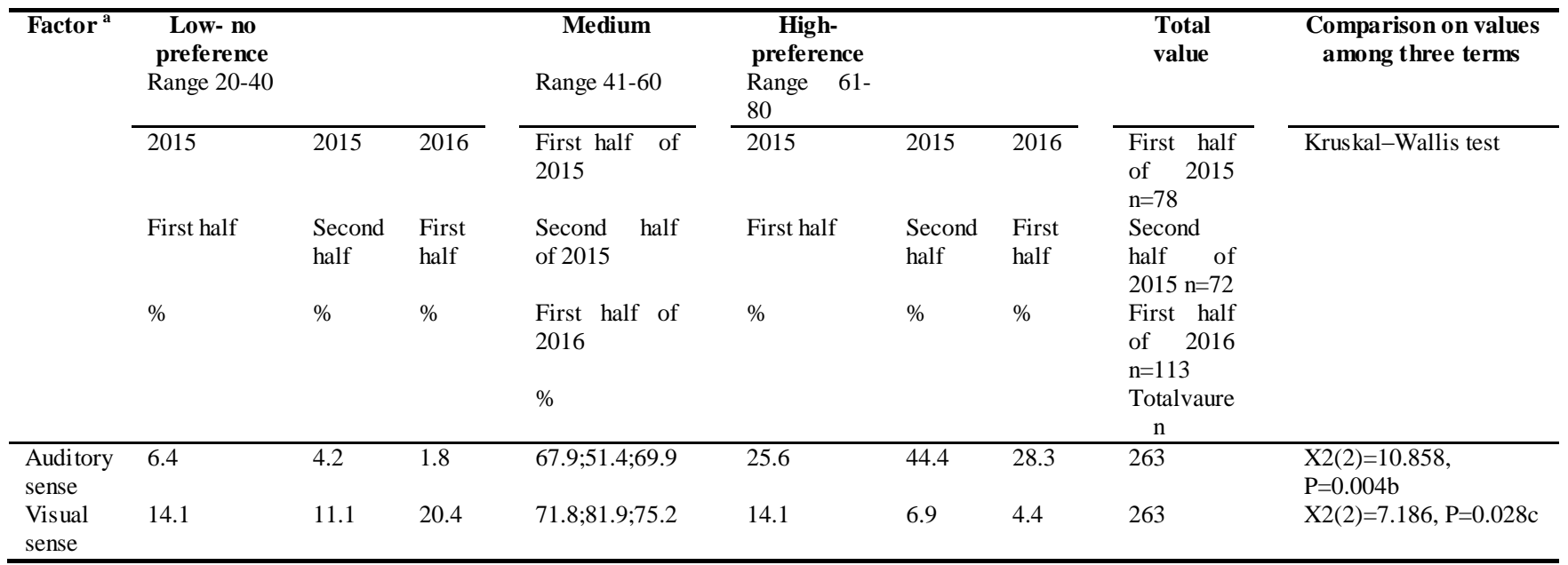

d. Adopt the Likert scoring method: 1 (never) to 5 (always)

e. When the value of $\mathrm{P}$ is less than 0.01 , the difference is significant.

\section{RESUlTS DisCUSSION}

The objective of this investigation is to study the difference in learning styles of English of English-majored normal students in three terms. We hope to find the relations between the personalities of students and their learning styles.

In term of whether the light for learning is dark or bright, environment is quiet or noisy, indoor layout is formal or informal and whether the demands on daily diet can be easily satisfied, the students can understand their own learning styles from the results of this study and create the learning environment which can meet their styles in later learning or at home.

The results are shown in individual variables. Compared with "preference", few students choose "no preference" while most students choose "whatever" which means no very strong preference. Items that are clearly marked with "preference" or "no preference" by students are the aspects that can promote or impede the learning process. All the students want the simplest and fastest methods to acquire knowledge and skills. Teachers should coordinate with the aspects that are most preferred by students and provide corresponding teaching strategies.

What seem to be more troublesome is those students who choose "whatever". This means that they are the students with multiple types of learning styles. Teachers may think that these students with multiple types of styles will adjust their learning methods according to the teaching modes. However, actually, if there are no special requirements or if they are not that interested in the learning contents, the learning of these students is very superficial and they only use their short-term memory. The learning environment of these students involves many factors and it will be relatively difficult to fully satisfy them. For the students who choose "whatever", the teachers need to fully arouse their enthusiasm and initiative when teaching contents. The teachers also can set certain restriction and constraint to them when necessary. It is shown in the results that only $16 \%$ of students possess high learning motivation and $9 \%$ of students possess high responsibilities. Therefore, the greatest challenge of teachers is to satisfy the inner motivation of students. Only when the inner motivation is motivated, can the students enjoy various learning challenges and figure out methods to accomplish the challenges. If the motivation comes from external world such as good impression to someone or obtaining certain awards, the students will be very passive. But only passively adapting to the teaching methods of teachers, the pressure on students will be very high.

It is shown in the results that even in the last academic year, the normal students still prefer the learning in high structure and hope that the authorities can be present when learning. Of course, no matter what level of education, the students need the clear objectives and academic atmosphere to tell them how to do. However, for the students facing their graduation from college and soon becoming teachers, we do not want such high requirements. The reason is that the teaching profession that normal students will engage in is limited by the legal norms. They will hope to obtain the confirmation of authorities when dealing with different student issues and teaching issues. In addition, two thirds of students hope that the schoolmates can be present when studying which can reduce the demands on teachers but obviously cannot solve all the issues.

What is thought-provoking is the data is that $8 \%$ of students prefer the visual type while $16 \%$ of students prefer non-vision type learning. But reading and self learning are inevitable in English learning. Coincidentally, it is shown in one research made by Pettigrew in 2011 that the weekly self learning time of students with elder ages are longer than that of those with smaller ages which is worthy of reflection of teachers. 
One third of students prefer the learning in auditory sense, tactile sense and kinesthesis. Most of courses arranged for the normal students in junior and senior in the school are lecturing courses. And this teaching method coincides with the learning style preferred by students. As early as 45 years ago, Dale once pointed out that the lecturing method should be appropriately reduced in the teaching methods because he found out that the students can remember the $10 \%$ of learning contents read by them, $20 \%$ of the contents heard by them and $30 \%$ of the contents displayed two weeks after having the classes but they can remember $90 \%$ of the learning contents taught and made by themselves. This proves the importance of the teaching methods such as discussion, case learning and situated learning, etc. however, after several decades, the implementation on those aspects of colleges is still insufficient.

To meet the requirements of learning styles of students in the classes and maintain the learning interests of students on class, teachers should adopt the teaching modes with multiple types and interaction type and change the teaching methods in each 40 to 50 minutes. According to the investigation of Pettigrew, even for the college students, their minds will start drifting away 40 minutes after class begins. Therefore, the teaching strategies on the aspects such as improving the interaction, participation and reflection should be added in the last-year college courses. On the teaching classes, encourage students who prefer non-vision learning to participate in.

No matter how many are the students on class, teachers should select various methods to keep every student work hard toward their established learning goals. Except for clearing the teaching objectives to student, teachers should also expand their teaching methods and display the teaching contents more effectively. The teachers should take following four issues into consideration according different students, different teaching contents and teaching activities: what kind of knowledge should they teach, why should they teach such kind of knowledge and how to teach as well as who should they teach.

\section{CONCLUSION}

The normal teachers and students have been trying to adjust the teaching and learning methods. However, they lack the related instructions. The PEPS questionnaire can investigate the learning styles of students in multiple aspects which is an excellent tool for investigation instruction.

It is shown in the results that the learning styles of English-majored normal students in junior and senior are various. However, for the learning contents that they are not interested in, most students choose "whatever". This needs the teachers to give more instructions to improve the motivation. According to the results, the teaching measures should be diversified and the discussion and interaction between teachers and students and among students should be increased. The PEPS questionnaire is very helpful to the learning and teaching in colleges. However, the investigations on English-majored normal students are insufficient. Hope this investigation can provide reference on this aspect.

\section{REFERENCES}

[1] Augustsson. A theoretical framework about leadership perspectives and leadership styles in the didactic room [M]. Hum. Resour. Stud. 2 (4)166-186. 2012.

[2] Dale. Audio- Visual Methods in Teaching [M]. New York : Holt Rinehart Winston. 1969.

[3] Dunn, Griggs. Learning Styles and the Nursing Profession [M]. New York: NLN Press. 1998.

[4] Evans. The Handbook of Intellectual Styles [M]. New York: Springer. 2012.

[5] Tan Dingliang. Study on Learning Styles and Its Application in Teaching Practice [J]. Jiangsu Higher Education, 1998.

[6] Zhou Ning. Distant China- Study on Western Images of China [M]. Beijing. Peking University Press, 2006.

[7] Zhang Guogang. Missioner in Ming and Qing Dynasties and European Sinology [M]. Beijing. China Social Sciences Press, 2005. 